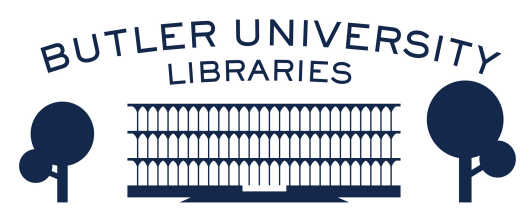

Journal of Hindu-Christian Studies

Volume 19

Article 9

January 2006

\title{
Singing of Satnam: Blind Simon Patros, "Dalit" Religious Identity, and "Satnami"-Christian Music in Chhattisgarh, India
}

Chad M. Bauman

Follow this and additional works at: https://digitalcommons.butler.edu/jhcs

Part of the Religion Commons

\section{Recommended Citation}

Bauman, Chad M. (2006) "Singing of Satnam: Blind Simon Patros, "Dalit" Religious Identity, and "Satnami"Christian Music in Chhattisgarh, India," Journal of Hindu-Christian Studies: Vol. 19, Article 9.

Available at: https://doi.org/10.7825/2164-6279.1364

The Journal of Hindu-Christian Studies is a publication of the Society for Hindu-Christian Studies. The digital version is made available by Digital Commons @ Butler University. For questions about the Journal or the Society, please contact cbauman@butler.edu. For more information about Digital Commons @ Butler University, please contact digitalscholarship@butler.edu. 


\title{
Singing of Satnam: Blind Simon Patros, Dalit Religious Identity and Satnami-Christian Music in Chhattisgarh, India
}

\author{
Chad M. Bauman \\ Butler University
}

CHRISTIANITY in every context-whether western or nonwestern, contemporary or ancient-emerges as a composite entity, combining elements of the religions and cultures that predate it with aspects of the Christian faith, in whatever form it arrives. There is, of course, nothing distinctly Christian about this process, for just as the expansion of Christianity into India involved the Indianization of Christianity, so too did the growth of Hinduism in Bali entail the Balinization of Hinduism. Other religions follow a similar pattern when they cross cultural boundaries.

This paper explores the Indianization of Christianity in late colonial Chhattisgarh, India, with special reference to a Satnami-Christian catechist and composer, Blind Simon Patros. ${ }^{\text {lxxvii }}$ Simon's music drew upon Chhattisgarhi linguistic and musical forms and emphasized continuity between Christianity and the Satnampanth, the dalit (lower-caste) community of Hindu Satnamis from which most Christians in the region had converted. Simon therefore contributed to the "indigenization" of Christianity in Chhattisgarh. However, the indigenization process cannot be properly considered without reference to the process of identity formation. For while the Chhattisgarhi Christian community at first embraced Simon's lyrics, which drew attention to the community's unexalted Satnami roots, it later, after having gained a degree of social respect, began to downplay or even deny its largely lower-caste provenance.

\section{Historical Context}

In the early nineteenth century, an illiterate Chamar from what is now the central Indian state of Chhattisgarh, Guru Ghasidas, returned from a pilgrimage to the famous Jagannath temple with a message for his followers. Ghasidas's message was similar to that of many Hindu reformers who had come before him. He told his followers, among other things, to abandon the worship of images, to avoid eating meat, to reject the use of brahmans as religious functionaries, and to devote themselves entirely to the one and only formless (nirgun) deity, whom he called "Satnam" (i.e., the True Name). The Guru's following grew, slowly at first, but by his death in 1850 he claimed a quarter of a million disciples, and by the century's end, nearly all members of the Chamar caste in Chhattisgarh had joined the panth and had begun calling themselves Satnamis. ${ }^{\text {xxviii }}$

In 1868, eighteen years after Ghasidas's death, the first western missionaries in the region, sent by German Evangelicals living in the United States, arrived in Raipur and later set up camp nearby, in Bishrampur. Given the downtrodden state of the Satnami community, these missionaries came to expect that all Satnamis would soon become Christian. Only a

CHAD M. BAUMAN, who received his Ph.D. from Princeton Theological Seminary, is Assistant Professor of Religion at Butler University, in Indianapolis, Indiana. His dissertation, "Identifying the Satnam: Hindu Satnamis, Indian Christians, and Dalit Religion in Colonial Chhattisgarh, India (1868-1947)," was completed in 2004, and he has since authored several articles related to the topic. His research interests include Hindu-Christian interaction, rural Hindu devotional and guru-focused movements, and hybrid religious identities. 
small percentage of Satnamis ever did convert, but the great majority of today's Christians in this area can trace their ancestry to the Satnampanth, and thus to the Chamar caste.

The Chamars are the largest dalit caste in India, and in Chhattisgarh they were at the time the largest of all communities. The Chamars were traditionally associated with tanning and leather goods. "Chamar" is, in fact, a derivative of chamra (with a short final "a"), i.e., hide or skin. Because of this association with the skins and bodies of dead animals, and in particular the sacred cow, Chamars were excluded from entry into Hindu temples and considered among the most ritually polluting of all castes, despite the fact that a large portion of Chamars in Chhattisgarh had abandoned their traditional occupation for agriculture. The very name "Chamar" has overtones of obscenity, and a related word, chamra (with a long final "a") when used in the proper context, is among the worst of all possible abuses.

Not surprisingly, Chamars in various parts of northern India have attempted to change their name. ${ }^{\text {lxxix }}$ In fact, followers of Ghasidas successfully petitioned the British government's census officials, in 1926, to have Satnamis distinguished from Chamars in all official documents. One side effect of this change was that "Satnami" came to be used as a caste name. Slowly, even Chhattisgarhi Chamars who had no connection to Ghasidas began to embrace the term, happy to abandon the derisive "Chamar."

One issue of great significance for those Satnamis who became Christian after 1868, therefore, was how they were to relate to their Satnami (and Chamar) past. Early on in the community's history, distinct Christian versions of that past developed which emphasized or invented (depending on one's perspective) links between Guru Ghasidas and the Christian community. Missionaries and Indian Christians consciously and unconsciously reconfigured the Satnami past in order to portray conversion to Christianity as the culmination of a process begun by Guru Ghasidas himself. The roots of Ghasidas's message were to be found, they maintained, in his encounter with missionaries in Cuttack, Orissa, during his pilgrimage to the Jagannath shrine in Puri. By telling stories such as this, Satnami-Christians were able to portray Guru Ghasidas's message as little more than a bastardized form Christianity, which was even further vitiated by the panth's subsequent gurus. This innovation situated Ghasidas, and thus the entire Satnami community, within the larger Christian story, and suggested that conversion did not represent the abandonment of the Guru's ideals, but rather their recovery.

Similarly, Christian leaders, working perhaps with information "remembered" by converts themselves, suggested that Ghasidas had predicted the arrival of a "white-faced man with a book under his arm." Christians of course believed that Ghasidas's prophecy referred to the missionaries who arrived half a century later. Ghasidas was thus reimagined as a forerunner of Christianity, a latter-day John the Baptist. Again, the implication, for Satnamis, was that becoming Christian was an act of obedience and faithfulness to the Guru's message, a fulfillment of the tradition rather than perfidy. ${ }_{\text {lxxx }}$

Neither Ghasidas's encounter with missionaries in Cuttack, nor his alleged prophecy regarding the "white-faced man" appear in the stories Satnamis tell about themselves, but the earliest Satnami-Christians appear to have embraced these accounts of Ghasidas's life as the "true" ones, and even, perhaps, participated, consciously or unconsciously, in their construction. Later, however, the community came to regard all reminders of its Satnami past, expressed or implied, as a liability. As the Satnami-Christian community gained ground in wealth, education, and social status, especially, beginning in the 1930 s and '40s, it sought, in a variety of ways, to distance itself from its low-caste roots. The Chamar and Satnami roots of the Christian community, emphasized by the Christian "myths" discussed above, were accordingly obscured or "forgotten."

It is in this context that we must consider the work of a regionally famous Satnami-Christian catechist, known as blind Simon Patros. Simon composed songs which drew upon local musical styles and employed the religious vocabulary of the Satnampanth. His music grounded Christianity in the cultural 
soil of Chhattisgarh, and his innovations were welcomed by Christians and Hindus alike. However, just as the Christian "myths" discussed above were rejected by the Christian community as their socioeconomic situation began to improve in the 1930 s and ' 40 s, so too was Simon's more explicit use of Satnami religious vocabulary.

\section{Shimon Drashtahin (Simon the Sightless)}

Simon's parents, Rachel (born Kari) and Patros (born Vishnath) were both Satnami converts to Christianity. When it became clear, in 1903, that their infant son, Simon, had become blind and would not recover his eyesight, the couple's happiness turned to sorrow, and they began to wonder, as some of their Satnami neighbors were suggesting, whether Simon's infirmity might be karmic retribution - the result of his, or their sins from a previous life. ${ }^{\text {lxxi }}$ Simon sensed from a very young age that his parents did not love him as they loved his siblings. ${ }^{\text {lxxii }}$ Once, during his infancy, he "fell" from an uncle's lap into an earthenware pot full of smoldering ashes. The severity of the wounds suffered in the incident led some to conjecture that the fall was not entirely accidental. ${ }^{\text {lxxiii }}$

As a result of not going to school, Simon came to associate with a rather unruly group of children, and oral Christian accounts of Simon's youth describe his juvenile antics as fondly and lovingly as Hindus speak of Krishna the Butterthief's youthful impishness. He was, nevertheless, one of the most attentive students at the mission's Sunday school, and could easily remember and repeat the stories teachers told in class. He also possessed a rather fantastical imagination, probably a fortunate side effect of his infirmity. He experienced the Christian passion narratives so profoundly, for example, that he was fourteen before he realized that Jesus was not actually crucified somewhere every Good Friday. In a passage that not only offers a glimpse of Simon's young mind, but also indicates disparate cultural and religious understandings regarding the "veracity" of myth, one Evangelical missionary reported:
All stories to him were fairy stories; those that he heard in the village as well as those that he heard in Sunday School and church. When attending a childrens [sic] meeting one day, the missionary said that she was going to tell them a true story...[When the meeting was] over with, Simon could hardly wait until he got to the missionary. "What," [he said,] "Are there true and false stories? Is not the story of the mouse and the cat just as true as the story of Daniel?" Hearing that this was not the case caused him several sleepless nights. ${ }^{\text {lxxiv }}$

Certainly Simon's mythic imagination contributed to his success as a musician and song-writer later in life. Simon's musical skills increased along with his knowledge of Christianity, and despite the fact that he lacked the requisite educational background, the mission sent Simon to its seminary in Raipur, the largest town in the area and the current capitol of Chhattisgarh, in 1920.

Simon's parents lived in the Christian colony of Ganeshpur, but they had not fully abandoned their pre-Christian religious practices. They continued, in secret, to worship Hindu deities (especially Nishana, one of the gods favored by Satnamis), honoring them on auspicious occasions and appealing to them for help in mundane affairs. They had even worshipped Simon as a vessel of Mata when he contracted smallpox during his childhood. Following the customary treatment of those stricken with the disease, Simon's family ritually washed his feet in milk and then drank it as a sign of their adoration of the devi. But whenever missionaries visited, they quickly and quietly removed the evidence of such practices. $1 \times x \times v$

In Sunday school, Simon and his brother heard the story of the Hebrew prophet, Gideon, who tore down his father's altar to Baal (Judges $6: 25 \mathrm{ff}$.), and the two boys vowed to destroy their parents' image of Nishana. Their father, Patros, considered the image sacrosanct, and believed that his own father and younger brother had died as a result of having discarded theirs. For some time, fear of divine reprisal prevented the boys 
from fulfilling their vow. One summer, however, while on break from his theological training, Simon was rooting around in the family house and happened upon the basket with which the family covered the altar of Nishana. (The altar is created by driving a stake into a mound of packed earth.) Simon resolved to get rid of the altar and waited until his family was out of the house on a market day. An account of the pivotal experience, perhaps glossed by time and subsequent events, but intriguing nonetheless, appears in his autobiography:

At four o-clock of that day in the month of May, I prayed [to] God for strength and courage like that of Gideon to destroy the idol. I removed the basket which covered it and began to pull the staff out of the ground. As I did so, I felt a strong impulse directing me not to pull it out, and I was frightened; but another and stronger impulse drove me to do so and throw it away. The words of my father came to mind, "This idol has killed your grandfather and uncle." My mind filled with conflicting ideas and I began to lose courage. In this extremity I turned to God and asked for help. I tried again to pull out the staff but could not. In desperation I turned to God and said, "Lord Jesus, give me the strength to gain the victory over this devil." As I touched the idol again, the devil made his final attempt to thwart me and I felt I would surely die. I was shaking, tears rolling down my cheeks; I thought I would stop breathing. I sat down to regain composure; I felt I was defeated and would not be able to remove the idol from our home.

Finally I summoned my courage again and prayed, "Lord Jesus, now I am going to pull that devil out. If I can do it this time I will know that thou art almighty and victorious. If I cannot do it I will believe that the god of my forefathers is true. Having prayed thus, I made my final attempt. All conflict had ceased, and with peace and strength in my heart and a smile upon my face, I grabbed hold of the Nishana and pulled it out of the ground. I put all the collected things of the god into an earthen pot, and covering myself with a towel, I went out of the village toward the brook [where I discarded the idol]. ${ }^{\text {'xxxvi }}$

Simon's father feared for his son's life, but decided to see what would happen before making any decisions. Simon remained healthy throughout the summer and even improved in health, significantly affecting the strength of the family's confidence in the Christian God.

Simon completed his degree at the top of his class in 1923, married a schoolteacher's daughter, and moved to another small town, Baitalpur, to work among lepers in the mission's leprosarium there. Some in the Christian community, perhaps revealing the influence of the Hindu view of infirmity as karmic retribution, questioned the fitness of a blind man for a ministerial job with the language of the Hebrew Scriptures: "For whatsoever man he be that hath a blemish, he shall not approach; a blind man or a lame..." (Lev. 21:18 KJV). Missionaries and Indian Christian leaders defended him with another passage: "Jesus answered, "Neither hath this man sinned, nor his parents: but that the works of God should be made manifest in him" (Jn. 9:3 KJV). lxxxvii

\section{Musical and Lyrical Indigenization}

In Baitalpur, Simon began to develop his musical skills more formally, teaching himself to play several instruments, including the tabla, dafali (a small tambourine) and chikara (a stringed, bowed instrument in the sarangi family). Later in life, Simon also learned to play the harmonium, but the instrument for which he was best known was the tambura, a long-necked instrument made from a gourd, with four strings that are plucked in accompaniment of a singer. Just after Simon arrived in Baitalpur, an Evangelical missionary, Theophil $\mathrm{H}$. Twente, reported that the blind evangelist's musical innovations had touched off an "awakening" in the region. 
Simon gave his first formal concert at the annual Chhattisgarhi Christian mela at Madku Ghat. He first put the story of the Prodigal Son to the tune of Alha, a well-known Bundelkhandi folk song traditionally sung by men and used with lyrics describing the heroic deeds of two brothers, Alha and Udal. Later, he sang a kirtan on the conversion of Paul. ${ }^{\text {lxxix }}$ The crowd was electrified, and collected funds to support Simon's musical development. It is clear that Simon's use of indigenous musical forms appealed to most Indians far more than the Hindi translations of western hymns to which they were accustomed. ${ }^{\text {xc }}$

After this episode, Simon began to perform kirtans more regularly. Along with bhajans, kirtans are the most common form of devotional song among Hindus in village India, and they are often sung in the spring and summer months when farmers are seeking divine protection and favor for the hot and rainy months to come. ${ }^{\mathrm{xci}}$ Kirtans are composed of a chorus [pallavi] and several verses [caranam], and usually expound a theme or tell a story. Like those of his Hindu counterparts, Simon's kirtan performances took place outside, in a village maidan, over the course of a few days or a week. He would play for several hours at a time and late into the evenings. $\mathrm{He}$ often performed seated on a dais- the same dais, in non-Christian villages, where Hindus played their kirtans and held Ramayana recitations. But occasionally he performed in the Pandvani style, in which the musicians would jump about while playing. In these more animated settings, the crowd often joined the performers in laughter and dance.

Simon's kirtans drew large crowds, sometimes of hundreds of people, from all castes and religious communities. Satnamis and Hindus in the region speak highly of his performances even to this day. Though nonChristians enjoyed Simon's kirtans primarily for their entertainment value, some appear to have respected Simon as a religious teacher. They were impressed by his religious passion, by his devotion (bhakti) to Jesus. ${ }^{\text {xii }}$

Virtually all Hindu scriptures are written in a poetic form and thus lend themselves easily to musical interpretation. Such is not the case for most Christian scriptures, and so Simon was forced to create his own musical lyrics. He is remembered for his evocative skill, for his ability to bring the drama and emotions of Biblical narratives to life. He sung the stories of Samson and Delilah, Queen Esther, Ananias and Saphira, and Jesus' birth, among others. His crowds were not infrequently brought to tears during his musical descriptions of poignant scenes such as Jesus' crucifixion, or the dissipation and destitution of the Prodigal Son. To those raised on recitations of the Ramayana and Mahabharata, many of these stories, particularly those from the Hebrew Scriptures, must have seemed of a rather familiar type.

The biblical Parable of the Prodigal Son, for example, reflects a social situation familiar to Chhattisgarhis. They would have understood the agonies of famines such as the one described in the parable-some of the worst famines in the region's history had occurred just before Simon's birth. And they would have shared the biblical audience's revulsion towards the swine among which the son was forced to live and eat. But Simon added touches of local nuance to his renditions of the stories, localizing them in order to draw in his audience. For example, in his Prodigal Son kirtan, the father is portrayed as a great malguzar (landlord), and the son a torpid vagrant who indolently plays marbles rather than going to school. Neither of these details appears in the biblical account (Luke 15:32). Simon also added an emotive description of the father's sorrow at the son's premature request for his inheritance, and suggests that the son threatened to strike the father with an axe in order to expedite the transaction. In another detail not found in the biblical version, the Prodigal Son's friends then make suggestions as to how he should spend his newfound wealth. One encourages him to buy a village and become a great zamindar, but the son eventually decides to throw something like a long, drawn out bachelor party. Simon drew life out of every sentence of the Christian scriptures, and could transform a short biblical passage into an artistic event lasting an entire evening. ${ }^{\text {xiii }}$

Simon also composed around 250 bhajans for use in the congregational setting. (Bhajans are songs of a diverse, loosely 
organized genre of relatively simple devotional tunes used in communal worship settings.) Though he created music for some of his bhajans, in most cases Simon put his own Christian lyrics to the tune of well-known Chhattisgarhi folk songs, such as the Bihav Git (Wedding Song) and Sua nach (Parrot Dance), or common rags, such as the Bhajan, Tambhura, Gazal, and Dadra. ${ }^{\text {xciv }}$ These folk songs are popular at Hindu festivals and weddings in Chhattisgarh, and many of them are still in use today.

Some of Simon's bhajans are catechetical, and articulate basic themes of Christian doctrine, like sin and soteriology, or the story of Jesus' birth, teachings, death and resurrection. The words of a song sung before each of Simon's kirtans and modeled after a form of Hindi poetic meter called savaiya, for example, offers a creed-like statement in four verses and covers creation, God's forgiveness, and Jesus' incarnation and resurrection. ${ }^{\mathrm{xcv}}$ Other bhajans fall within the Hindu bhakti tradition, and express the composer's love and devotion for Jesus the Guru. In one song, set to the Goran bihav rag (a tune used in Gond weddings), Simon writes, "I have seen so many gods and goddesses / They died like humans / But Yishu Masih [Jesus the Messiah], you are righteous, / Thus I have made you my Guru." "xcvi The anti-idolatry theme adumbrated in this passage is a common one for Simon. A line from a song based on the Tambhura rag asserts, "Iron idols rust, and wooden idols spoil / Those who choose a Guru without thinking suffer much."xcvii Like those in this bhajan, some of Simon's lyrics appear to be aimed directly at the Satnamis. Another song, also set to the Tambhura rag emphasizes that earthly gurus are "without conscience" and "bear false witness against each other." "xcviii (This is a reference not to Ghasidas, but to his successors, his sons and grandsons who were unable to uphold Ghasidas's high standard of moral behavior.) Yet another lyric refers to Jesus as the "Sat Guru" (the True or Real Guru). ${ }^{\text {xcix }}$

Healing is another regular theme in Simon's bhajans, perhaps not surprisingly, given his own disability and the fact that he worked for many years at the Baitalpur leprosarium. Those afflicted by leprosy in Simon's audiences would have understood lyrics such as those in one song, set to the Gazal rag, in which God is portrayed in the aspect of a doctor, washing wounds and applying ointment. In the same song, the interminable and impossibly loud sound of the insects that bore through the rafters of rural Indian homes becomes a metaphor for sin. "The worms of $\sin$ are in my heart / Gnawing, gnawing, gnawing, the worms bore on. Because of this I weep." (In the phrase translated here as "gnawing, gnawing, gnawing," Simon repeats the onomatopoeic Chhattisgarhi word, kut, that approximates the sound of the wood-boring insects.)

The lyrics of some of Simon's bhajans bear no resemblance to those traditionally associated with the rags on which they are based. For example, Simon set a description of Jesus' birth to the tune of the popular Sua nach, a regional harvest song of playful lyrics addressed, metaphorically, to a parrot (suana). ${ }^{\mathrm{ci}}$ But in other lyrics, Simon builds upon the ideas, images, and emotions related to the rags, transforming these evocative associations by situating them in a new context. For instance, in the chorus of a bhajan set to the Kevat Kahani rag, a tune usually accompanied by lyrics containing kahanis (stories) about kevats (members of the fisher and ferrier jati), Simon portrays Jesus as a ferryman: "Savior of life, captain of the boat, $\mathrm{O}$ beloved Jesus / Ferry me across the river, ferry me across the river." The first verse continues the metaphor, "The river is too deep and my boat is so old / Jesus my beloved ferryman (kevat), ferry me across the river." cii

In a bhajan based on the Bihav Git, Simon exploits the grammar and style of the song's traditional lyrics for evangelical purposes. The Bihav Git is actually a series of songs used at different stages during traditional Hindu weddings, and is still in use today (though not by Christians). The tune employed by Simon is from the section of the tune called telchaghi, which is sung while the bride is being anointed with oil (tel). Though Simon's lyrics involve the birth of Christ, their style clearly borrows from that of the Bihav Git. Simon 
transforms the aesthetic coupling of the traditional lyrics into an effective catechetical tool. Compare:

\section{Bihav Git}

Where $O$ Ginger, where $O$ Ginger, were you born?

Where have you taken birth [avatar]?

In the marar [vegetable grower's jati] para.

Marar para sister, I have taken birth.

I have taken birth in the world [pirthi].

Where O karsa [earthen pot]

where O karsa, were you born?

Where have you taken birth?

In a black ant hill [possibly a metaphor for a kiln],

A black ant hill, sister, I have taken birth.

I have taken birth in the kumhara [potter caste's] para.

Where $\mathrm{O}$ maur [a feathered, ceremonial crown], where O maur, were you born?

Where have you taken birth?

In the jungle and bushes,

In the jungle and bushes, sister, I have taken birth.

In the marar para have taken birth.

Where O parra [a woven bamboo plate], where O parra, were you born?

Where have you taken birth?

In the mountains and hills,

In the mountains and hills, sister, I have taken birth.

In the kanrara [the caste that makes parras] para

I have taken birth.

Our bride, our bride, so beautiful.

Teli [member of the oil-pressing jati],

press oil and give it to us.

\section{Simon's Bhajan}

From which country, from which country thave you come]?

In which country have you taken birth [avatar]?

From the land of heaven, the land of heaven [I have come].

I have taken birth in the world [duniya].

Jesus tell me, Jesus tell me, from whose womb did you take birth?
In Bethlehem, in Bethlehem, I took birth from Mary's womb.

What was your covering, what was your covering?

Where did you find your bed and bedding?

I covered myself in rags. I covered myself in rags.

Straw was my bedding, and I slept in a sheep's manger.

Why have you done this, why have you done this?

What is the great work for which you came?

I have come for sinners. I have come for sinners.

I have come to save sinners.

How did you save the sinners? How did you save the sinners?

How have you rescued them from $\sin$ ?

For the sake of sinners, for the sake of sinners, I have shed my blood.

You have shed your blood. You have shed your blood.

Tell me the secret of how you saved sinners.

I have shed my tears. I have shed my tears.

I died, was raised, and purchased the life of sinners.

\section{Conclusion}

It is not surprising, given Simon's loving, masterful use of Chhattisgarhi and his skillful utilization of local lyrical and musical forms, that his bhajans were exceedingly popular. Simon's songbook, Chhattisgarhi Christian Bhajans, which contained around sixty of his songs (some editions had fewer), was first published in 1937, and was reprinted nearly every year until the end of the 1940s. It was among the mission's best-sellers each year, and sometimes topped the list. By the end of its run it had sold over fifty thousand copies. ${ }^{\text {ciii }}$ This number is particularly striking when one keeps in mind that in the 1930s there were fewer than fifteen thousand Christians in all of Chhattisgarh, and that less than ten percent of the general population could read. Clearly Simon's popularity was such that large numbers of non-Christians and illiterate Chhattisgarhis were purchasing his bhajan books. Simon did not appear to use his musical skills for the 
express purpose of evangelism, though his passion and devotion often had evangelical repercussions; many Satnami converts attributed their initial interest in Christianity to Simon's kirtans.

Blind Simon Patros translated the myths and beliefs of Christianity into an indigenous musical idiom, and appealed, above all, to the Satnami community from. which his parents had come. In the lyrics of a song set to the Bhajan rag placed prominently for effect at the very beginning of his bhajan book, Simon refers four times to Jesus as "Satnam." Clearly Simon was attempting, like those who "invented," promoted, and published distinctly Christian accounts of the Satnami past, to forge a connection between the Satnampanth and Christianity. But just as the Christian community later rejected the implication of these historical "myths," so too did it reject the implications of Simon's indigenized music.

After four days of revelry, sleeping in tents, and bathing in rivers at the 2004 Madku Ghat mela, where Simon had had his performing debut almost a century earlier, I was interviewing a young woman who knew some of Simon's songs. I showed her a copy of Simon's songbook, which I had discovered in an American archive and taken along to India. Pointing at the first bhajan, the one in which Simon refers so frequently to Jesus as "Satnam," I asked her whether she knew the traditional Chhattisgarhi words of the tune. Taking a look at the songbook, and noticing the word "Satnam," she declared Simon's lyrics to be the pre-Christian, traditional Chhattisgarhi words to the tune. In the version of Simon's song that she knew, and that is now popular, the words had been changed; "Satnam" had been removed and replaced by "Yishu." civ Later redactors of the song, apparently uncomfortable with the emphasis Simon laid on the continuities between the Satnami and Christian faith (with the encouragement of missionaries), had expurgated his use of the Satnami divine name.

As Christianity develops in any particular locale, it does so in conversation with the pre-Christian past. However, as the Satnami-Christian story demonstrates, the preChristian past cannot simply be dealt with once and for all, but remains a live issue well after Christianity becomes established. The formation of communal identity is an amorphous, ever-changing process. What constitutes an instance of acceptable "indigenization" thus changes from period to period.

Despite the fact that subsequent generations of Satnami-Christians have rejected some of Simon's attempts at rooting Christianity in the cultural and religious soil of Chhattisgarh, he did contribute significantly to the Chhattisgarhization of Christianity in a variety of ways. The mere fact that Simon employed local languages to express his faith, for example, would have influenced how it was received. Chhattisgarhi words, like all words, would have come freighted with their own semiotic associations, and, when applied to Christianity, would have tinctured the appropriation of Christian ideas. Think, for example, of Simon's use of the Chhattisgarhi (and Hindi) term avatar. The fact that Simon chose this term to speak about Jesus' incarnation would have affected the way that it was understood. Similarly, Simon's use of the term, "Satnam" for Jesus would have conjured up a whole range of associations for those Satnamis who used the term to refer to their God, and these associations would have attached themselves to the figure of Jesus.

Likewise, the local folk tunes that Simon employed would have evoked certain emotional states, because of the traditional lyrics attached to them and because of the settings in which the folk tunes were traditionally sung. Simon's use of these folk tunes with Christian lyrics would therefore have evoked an emotional response, conscious or unconscious, that could not have failed to influence the way in which those lyrics were understood.

Musicians, poets, historians, and older Christians in the area, especially those who were born in the early part of the twentieth century, bear a certain nostalgia for Simon's songs and for his ability to draw continuities between Christianity and the Satnampanth. But more recent generations of Christians in Chhattisgarh have rejected Simon's desire to forge connections between his Christianity and his family's cultural and religious heritage. To 
them, Simon's use of Satnami religious vocabulary was ill-advised and unwelcome. Nevertheless, Simon was a creative cultural and religious transgressor of religious boundaries, a Satnami-Christian for whom the hyphen was important, and another example of the infinite variety of interstitial and hybrid religious expression.

kxxyii Research for this paper'was conducted in the Raipur and Bilaspur districts of Chhattisgarh, a new state in central India, in the first half of 2004 , and in the Archives of the Evangelical Synod (hereafter AES) at Eden Theological Seminary, St. Louis, Missouri. An earlier version of this paper was delivered at the Mid-Atlantic Regional Meeting of the Association for Asian Studies, 23 October 2004. The author would like to thank Rev. Samsher Samuel for his assistance with the research for this article Ixxviii Saurabh Dube, Untouchable Pasts: Religion, Identity, and Power among a Central Indian Community, 1780-1950 (Albany: SUNY.Press, 1998), p. 50.

Ixxix On Chamars in Uttar Pradesh who call themselves "Raidasi," see Bernard Cohn, "The Changing Status of a Depressed Caste," in An Anthropologist among the Historians and Other Essays, ed. Bernard Cohn (Delhi: Oxford University Press, 1987), p. 264.

${ }^{1 \times x x}$ For a detailed discussion of the development of these stories from "myth" to "history," see Chad Bauman, "Identifying the Satnam: Hindu Satnamis, Indian Christians, and Dalit Religion in Colonial Chhattisgarh, 1868-1947" (Ph.D. Dissertation, Princeton Theological Seminary, 2004). For an overview of Christian and Satnami versions of the Satnami past, see Dube, Untouchable Pasts, pp. 193204.

Ixxxi Simon Patros, Simon Patros of India: A Miracle of God's Grace (St. Louis: Board of International Missions, Evangelical and Reformed Church, Inc., 1954), p. 10.

Ixxxii Shyama Kumari Patros (daughter-in-law of Simon), interview by author, Raipur, Chhattisgarh, 9 April 2004.

Ixxxiii M. P. Albrecht, "Blind Simon," undated, AES 84-9b Simo5.

Ixxxiv Ibid.

Ixxxv Patros, Simon Patros of India, p. 15.

Ixxxvi Ibid., pp. 44-45.

1xxxvii Ibid., p. 33. Here again, the Hebrew scriptures seem more consonant with the pre-Christian worldview of Chhattisgarh's Christians than the New Testament. lxxxviii Twente to Paul A. Menzel, October 1923, AES 82-13a Pr91, Annual Reports, no. 8, 1923. ${ }_{\text {lxxxix }}$ Patros, Simon Patros of India, p. 39.

${ }^{x c}$ On a far more widely known Indian Christian who employed Tamil musical and poetic forms in the production of Christian songs, see Indira Viswanathan Peterson, "Bethlehem Kuravanci of Vedanayaka Sastri of Tanjore: The Cultural Discourses of an Early-Nineteenth-Century Tamil Christian Poem," in Christians, Cultural Interactions, and India's Religious Traditions, ed. Judith M. Brown and Robert Eric Frykenberg (Grand Rapids: William B. Eerdmans Publishing Company, 2002), pp. 9-36.

${ }_{\text {xci }}$ For more on rural devotional songs, see Susan S. Wadley, "Texts in Context: Oral Tradition and the Study of Religion in Karimpur," in American Studies in the Anthropology of India, ed. Sylvia Vatuk (New Delhi: Manohar Publications, 1978), pp. $326 \mathrm{ff}$. xcii Itwari and Parshadi (both informants use only one name), interview by author, Dekhuna, Chhattisgarh, 23 March 2004.

xciii Much of the information in this paragraph comes from Theodore Twente, "The Gospel in Chhattisgarhi Garb," undated, AES 82-I4 Qu2, Twente, Th. H., Quarterly Reports, Articles, Newsletters.

${ }^{\text {xciv }}$ For more on these Chhattisgarhi musical forms, and collections of the lyrics traditionally sung to them, see Sharif Mohammad, Madhyapradesh ka lok sangit (Bhopal: Madhyapradesh Hindi Granth Akadmi, n.d.); and Hanumant Naidu, Chattisgarhi lok-giton ka loktatvik tatha manovaijanik anushilan (Nagpur, Madhya Pradesh, India: Vishvabharati Prakashan, 1987); and Dayashankar Shukla, Chattisgarhi loksahitya ka adhyayan (Raipur, Chhattisgarh, India: Jyoti Prakashan, n.d.).

${ }^{x e v}$ Simon Patros, Chhattisgarhi Christian Bhajans (Raipur: Evangelical Book Depot, 1940), \#2. xcvi Ibid., \#7.

xcvii Ibid., \#20.

xcviii Ibid., \#16.

xcix Ibid., \# 23.

${ }^{\mathrm{c}}$ Ibid., \#12.

${ }^{\text {ci }}$ Ibid., \#4. For more on the Sua nach, see Joyce Burkhalter Flueckiger, Gender and Genre in the Folklore of Middle India (Ithaca: Cornell University Press, 1996), pp. 77 ff.

cii Patros, Chhattisgarhi Christian Bhajans, \#15.

ciii M. P. Davis, "The Mission Pen," 1941, AES 82$13 b$ St2 7a, Literature Committee (Publications).

${ }^{\text {civ }}$ Smita Baksh and C. P. Samuel, Madku Ghat, Chhattisgarh, 13 February 2004 (interview by author). 
-

Journal of Hindu-Christian Studies, Vol. 19 [2006], Art. 9

36 Chad M. Bauman

https://digitalcommons.butler.edu/jhcs/vol19/iss1/9

DOI: $10.7825 / 2164-6279.1364$ 